\title{
Biological Impact of Divergent Land Management Practices on Tomato Crop Health
}

\author{
Dan O. Chellemi, Tiehang Wu, Jim H. Graham, and Greg Church
}

First author: U.S. Department of Agriculture-Agricultural Research Service, U.S. Horticulture Research Laboratory, Fort Pierce, FL 34945; second author: Georgia Southern University, Statesboro 30460; third author: University of Florida, Citrus Research and Education Center, Lake Alfred 33850; and fourth author: Texas AgriLife Extention Service-Collin County, Texas A\&M University. Accepted for publication 3 February 2012.

\begin{abstract}
Chellemi, D. O., Wu, T., Graham, J. H., and Church, G. 2012. Biological impact of divergent land management practices on tomato crop health. Phytopathology 102:597-608.

Development of sustainable food systems is contingent upon the adoption of land management practices that can mitigate damage from soilborne pests. Five diverse land management practices were studied for their impacts on Fusarium wilt (Fusarium oxysporum f. sp. lycopersici), galling of roots by Meloidogyne spp. and marketable yield of tomato (Solanum lycopersicum) and to identify associations between the severity of pest damage and the corresponding soil microbial community structure. The incidence of Fusarium wilt was $>14 \%$ when tomato was cultivated following 3 to 4 years of an undisturbed weed fallow or continuous tillage disk fallow rotation and was $>4 \%$ after 3 to 4 years of bahiagrass (Paspalum notatum) rotation or organic production practices that included soil amendments and cover crops. The incidence of Fusarium wilt under conventional tomato production with soil fumigation varied from $2 \%$ in 2003 to $15 \%$ in 2004 . Repeated tomato cultivation increased Fusarium wilt by $20 \%$ or more except when tomato was grown using organic practices, where disease remained less than $3 \%$. The percent of tomato roots with galls from Meloidogyne spp. ranged from 18 to $82 \%$ in soil
\end{abstract}

ABSTRACT previously subjected to a weed fallow rotation and 7 to $15 \%$ in soil managed previously as a bahiagrass pasture. Repeated tomato cultivation increased the severity of root galling in plots previously subjected to a conventional or disk fallow rotation but not in plots managed using organic practices, where the percentage of tomato roots with galls remained below $1 \%$. Marketable yield of tomato exceeded $35 \mathrm{Mg} \mathrm{ha}^{-1}$ following all land management strategies except the strip-tillage/bahiagrass program. Marketable yield declined by 11, 14, and 19\% when tomato was grown in consecutive years following a bahiagrass, weed fallow, and disk rotation. The composition of fungal internal transcribed spacer 1 (ITS1) and bacterial 16S rDNA amplicons isolated from soil fungal and bacterial communities corresponded with observed differences in the incidence of Fusarium wilt and severity of root galling from Meloidogyne spp. and provided evidence of an association between the effect of land management practices on soil microbial community structure, severity of root galling from Meloidogyne spp., and the incidence of Fusarium wilt.

Additional keywords: disease suppressive soil, organic agriculture, soil fumigants, soil microbial diversity, sustainable pest management.
Producers of high value, fresh market vegetables must balance concerns over environmental stewardship and escalating production costs with the risk of economic damage from soilborne pests. This is especially true in Florida where a significant portion of the fresh market vegetable crops are planted within the confines of the ecologically sensitive Florida Everglades Watershed (FEW). Within this $25,000 \mathrm{~km}^{2}$ region, agriculture, urban development, and habitat restoration compete for the same resources. Initially, the large reserve of "virgin soil" in the FEW allowed vegetable growers to employ a "migratory approach" to mitigate damage from soilborne pests (23). Crops were rarely cultivated in the same field twice, allowing growers to avoid the build-up of soilborne pests. Eventually the availability of virgin soil was exhausted, forcing growers to return to sites where crops were previously cultivated. To mitigate the eventual build-up of soilborne pests, the industry adopted a single tactic pest management approach based upon soil fumigation with mixtures of methyl bromide and chloropicrin $(19,56)$. When a phase out of produc-

Corresponding author. D. O. Chellemi; E-mail address: dan.chellemi@ars.usda.gov

* The $e$-Xtra logo stands for "electronic extra" and indicates that Figures 4, 5, 6, and 7 appear in color online.

http://dx.doi.org/10.1094/PHYTO-08-11-0219

This article is in the public domain and not copyrightable. It may be freely reprinted with customary crediting of the source. The American Phytopathological Society, 2012. tion and importation of methyl bromide was implemented due to its destructive effects on stratospheric ozone (49), alternative fumigants were developed as drop-in replacements $(11,21,33)$. Most agricultural soils in the FEW are poorly drained Alfisols and Spodosols comprised mostly of sand, are very low in organic matter, and situated over perched water tables $(20,35)$. These soils are conducive to surface water infiltration of nutrients and pesticides during periods of abundant rainfall. Additional economic and logistical concerns pertaining to buffer zone and personal protective equipment requirements for soil fumigants (50) further limit the feasibility of a single-tactic approach for managing soilborne pests.

An alternative "proactive approach" can be accomplished by incorporating methods of pest suppression into the design of crop production systems (8). This approach was first attempted in the FEW in 1952 when pangolagrass (Digitaria decumbens) was spread into row middles and allowed to establish between the tomato plants to suppress damage from root-knot (Meloidogyne spp.) nematodes (23). However, pangolagrass proved too difficult to establish in a timely and repeatable manner and the system was abandoned. Perennial grass rotations such as bahiagrass (Paspalum notatum) pasture can significantly reduce the impact of some major soilborne pests of tomato, including southern blight (incited by Athelia rolfsii) and Fusarium wilt (incited by Fusarium oxysporum f. sp. lycopersici), and have been effectively used for nematode management $(5,17,25,43)$. An alternative low-input production system designed for tomato (Solanum lycopersicum) 
that integrates strip-tillage practices into established bahiagrass pasture was shown to be technically feasible on a large scale (13). However, the ability of this low input system to extend pest suppression beyond a single tomato crop and its applicability to agroecosystems in the FEW have not been examined.

Organic and reduced-input systems can alleviate root diseases when compared with conventional systems (51) and applications of urban plant debris and broiler litter up to 67 and $22 \mathrm{Mg} \mathrm{ha}^{-1}$, respectively, can reduce populations of plant-parasitic nematodes and the incidence of soilborne diseases $(10,41)$. Reductions in soilborne disease from incorporation of composted organic amendments has been demonstrated $(32,47)$, although their effects may be variable especially during the transitional period from a conventional to organic production system (2). Rotational crops can reduce the impact of soilborne pests (34) and can suppress damping-off during the transitional period (2), although their adaptation to tomato farms with established pest populations has not been fully investigated. Cover cropping combined with soil solarization was shown to reduce populations of herbivorous nematodes on pepper cultivated in North Florida (53).

Land management strategies commonly employed in the FEW include a "weed fallow" approach where fields are left undisturbed for extended periods of time and a "disk fallow" approach where fields receive periodic tillage to maintain fields free of vegetation (D. O. Chellemi, personal observation). Despite the popularity of these land management approaches, scientifically based information regarding their concomitant and extended effects on pest suppression, soil quality, and marketable yield of tomato is lacking.

Paramount to incorporating land management practices into the design of multiple goal oriented cropping systems is knowledge of their associated impacts on pest suppression, soil quality, soil microbiology and crop productivity. The objectives of this study were to measure the effect of five diverse land management practices on the incidence of Fusarium wilt, severity of root galling from Meloidogyne spp., and marketable yield of tomato and to identify associations between land management effects on soil fungal and bacterial community composition and the incidence of Fusarium wilt and damage from Meloidogyne spp.

\section{MATERIALS AND METHODS}

Experimental site. The field experiment was located near Fort Pierce, Florida $\left(27.22^{\circ}\right.$ north and $80.29^{\circ}$ west $)$ in the southeastern United States. Prior to the experiment, the site was a commercial farm subjected to 10 consecutive years of conventional tomato production practices including soil fumigation with methyl bromide and chloropicrin. The site had a history of soilborne pests including Meloidogyne spp. and F. oxysporum f. sp. lycopersici. Data were collected in years 4 and 5 of a 5-year-study investigating the impacts of land management strategies on soil quality, microbial ecology, and crop production. The experimental site consisted of a single soil type, (Pineda fine sand-loamy, siliceous, hyperthermic, Arenic, Glossaqualf) (54), commonly used for citrus, sugarcane, and vegetable production in the FEW $(20,35)$. The soil texture was $94-3-3 \%$ sand-silt-clay, respectively, and the soil bulk density was $1.4 \mathrm{~g} \mathrm{~cm}^{-3}$ at a 0 to $30 \mathrm{~cm}$ sample depth. Mean annual precipitation during the 5-year-period was $1,308 \mathrm{~mm}$ with $56 \%$ of the amount occurring from June through September and the extreme maximum and minimum temperatures was 35.7 and $-0.3^{\circ} \mathrm{C}$, respectively. Five agricultural land management practices commonly employed within the FEW were selected and arranged in a randomized complete block design with six replications. Each replicate plot was 0.16 ha $(23.0 \times 76.0 \mathrm{~m})$. Land management programs were (i) conventional; (ii) disk fallow; (iii) weed fallow; (iv) organic; and (v) bahiagrass. The experiment was initiated in July 2000. A chronological summary of the land management practices is given in Table 1 and a list of the planted hosts and fertility inputs for the land management systems are provided in Table 2. In 2003, year 4 of the experiment, tomato was planted in the south half of each replicate plot. In 2004, tomato was planted in the south and north halves of each plot. Thus for the disk fallow, weed fallow, organic, and bahiagrass land management strategies, the south half of each plot provided an opportunity to evaluate two successive crops of tomato following 3 years of the respective land management practices. Work describing the impact on the five land management strategies on changes in soil microbial diversity and root colonizing fungi has previously been published (40,57-59).

TABLE 1. Summary of land management practices of a 5-year cropping system study (July 2000 through January 2005) ${ }^{\mathrm{a}}$

\begin{tabular}{|c|c|c|c|c|}
\hline $\begin{array}{l}\text { Land management } \\
\text { strategy }\end{array}$ & Year $^{\mathrm{b}}$ & July & August to December & January to June \\
\hline Conventional $^{c}$ & & Tillage & $\begin{array}{l}\text { Soil fumigation, synthetic fertilizer, herbicides, } \\
\text { raised plastic-mulched beds, tomato transplanted }\end{array}$ & Periodic tillage \\
\hline Organic ${ }^{\mathrm{e}}$ & $\begin{array}{l}2000 \text { to } 2003 \text {-north } \\
2003 \text {-south, } 2004\end{array}$ & $\begin{array}{l}\text { Broiler litter and urban plant } \\
\text { debris added to soil } \\
\text { Broiler litter and urban plant } \\
\text { debris added to soil }\end{array}$ & $\begin{array}{l}\text { Cover crop } \\
\text { Soil solarization, raised plastic-mulched beds, } \\
\text { tomato transplanted }\end{array}$ & $\begin{array}{l}\text { Cover crop } \\
\text { Cover crop }\end{array}$ \\
\hline
\end{tabular}


Conventional tomato production. A $63.4 \%: 34.7 \%$ mixture of 1,3-dichloropropene: chloropicrin (Telone C-35, Dow AgroSciences, Indianapolis, IN) was broadcast applied annually at $276 \mathrm{~kg} \mathrm{ha}^{-1}$ in August with a low disturbance, deep-placement coulter system $(11,44)$. Subsequent to fumigation, the herbicides napropamide ((R,S)-N,N-diethyl-2-(1-naphthyloxy) propionamide) and trifluralin (a,a,a-trifluoro-2,6-dinitro-N,N-dipropyl-ptoluidine) were applied at 2.2 and $0.6 \mathrm{~kg} \mathrm{ha}^{-1}$, respectively, to the soil surface. Fertilizer was incorporated into raised, drip irrigated, plastic-mulched beds at rates presented in Table 2. In 2003 and 2004 , additional $\mathrm{N}-\mathrm{P}_{2} \mathrm{O}_{5}-\mathrm{K}_{2} \mathrm{O}$ was drip applied at daily intervals. Five-week-old tomato seedlings ('Florida 91') were transplanted into the plastic mulched beds on 27 September 2000, 19 September 2001, 9 September 2002, 2 September 2003, and 6 October 2004. Tomato plants were pruned and cultivated on a trellis using commercial production methods. Plots were scouted weekly and treated when necessary for foliar pests. Foliar applications of copper hydroxide (Champ WG, NuFarm Americas, Morrisville, NC) and Bacillus spp. (Serenade, AgraQuest, Inc., Davis, CA) were applied as needed for control of bacterial spot (Xanthomonas campestris pv. vesicatoria) and target spot (Corynesporum cassicola) and Bacillus thuringiensis (XenTari DF, Valent BioSciences Corp., Libertyville, IL) and spinosdad (Entrust, Dow AgroSciences) were applied as needed to control foliar insect pests including thrips and various Lepidoptera pests.
Organic production. Broiler litter consisting of a mixture of pine shavings and manure that was dry stock, aged between 6 and 12 weeks in static row piles and having ash content below $25 \%$ was spread onto plots together with partially composted, tub ground, urban plant debris in July 2000 to 2004. Application rates ranged from 20.8 to $25.3 \mathrm{Mg} \mathrm{ha}^{-1}$ for the broiler litter and 60.3 to $75.3 \mathrm{Mg} \mathrm{ha}^{-1}$ for urban plant debris. Corresponding fertility rates are presented in Table 2. Sunn hemp (Crotalaria juncea L.) was planted annually at a seeding rate of $33.6 \mathrm{~kg} \mathrm{ha}^{-1}$ several weeks after the organic amendments were applied (Table 1). In February, the sunn hemp was mowed, incorporated into soil and Japanese millet (Echinochloa crusgalli var. frumentacea) planted at a seeding rate of $21 \mathrm{~kg} \mathrm{ha}^{-1}$. In July 2003, soil solarization was conducted on raised, plastic mulched beds in the south half of each plot using methods described by Chellemi et al. (12). In July 2004, solarization was conducted on both the south and north halves of each plot. Five-week-old tomato seedlings ('Florida 91') were transplanted into solarized, plastic mulched beds on 2 September 2003 and 6 October 2004. Tomato plants were pruned and cultivated on a trellis using commercial production methods. Plots were scouted weekly and treated when necessary for foliar pests using the same materials previously described under the conventional program. All pest control products were approved by the Organic Materials Review Institute (OMRI, Eugene, OR) for use in certified organic production.

TABLE 2. Planted hosts and fertility inputs for land management strategies

\begin{tabular}{|c|c|c|c|c|c|}
\hline \multirow[b]{2}{*}{ Management strategy } & \multirow[b]{2}{*}{ Plants } & \multicolumn{3}{|c|}{ Nutrients $^{\mathrm{a}} \mathrm{kg} \mathrm{ha}^{-1}$} & \multirow{2}{*}{$\begin{array}{l}\% \text { applied by } \\
\text { drip irrigation }\end{array}$} \\
\hline & & $\mathrm{N}$ & $\mathrm{P}_{2} \mathrm{O}_{5}$ & $\mathrm{~K}_{2} \mathrm{O}$ & \\
\hline \multicolumn{6}{|l|}{2000} \\
\hline Disk fallow ${ }^{\mathrm{b}}$ & None & 0.0 & 0.0 & 0.0 & 0 \\
\hline Weed fallow ${ }^{\mathrm{c}}$ & Undisturbed weed community & 0.0 & 0.0 & 0.0 & 0 \\
\hline Bahiagrass & Bahiagrass & 56.0 & 0.0 & 56.0 & 0 \\
\hline Conventional $^{\mathrm{d}}$ & Tomato & 252.0 & 0.0 & 252.0 & 0 \\
\hline Organic ${ }^{e}$ & Sunn hemp and Japanese millet & 658.0 & 833.3 & 508.3 & 0 \\
\hline \multicolumn{6}{|l|}{2001} \\
\hline Disk fallow & None & 0.0 & 0.0 & 0.0 & 0 \\
\hline Weed fallow & Undisturbed weed community & 0.0 & 0.0 & 0.0 & 0 \\
\hline Bahiagrass & Bahiagrass & 56.0 & 0.0 & 56.0 & 0 \\
\hline Conventional & Tomato & 252.0 & 0.0 & 252.0 & 0 \\
\hline Organic & Sunn hemp, Japanese millet & 518.0 & 591.3 & 544.5 & 0 \\
\hline \multicolumn{6}{|l|}{2002} \\
\hline Disk fallow & None & 0.0 & 0.0 & 0.0 & 0 \\
\hline Weed fallow & Undisturbed weed community & 0.0 & 0.0 & 0.0 & 0 \\
\hline Bahiagrass & Bahiagrass & 56.0 & 0.0 & 56.0 & 0 \\
\hline Conventional & Tomato & 252.0 & 0.0 & 252.0 & 0 \\
\hline Organic & Sunn hemp and Japanese millet & 485.1 & 711.5 & 485.1 & 0 \\
\hline \multicolumn{6}{|l|}{ 2003-north half of plots } \\
\hline Disk fallow & None & 0.0 & 0.0 & 0.0 & 0 \\
\hline Weed fallow & Undisturbed weed community & 0.0 & 0.0 & 0.0 & 0 \\
\hline Bahiagrass & Bahiagrass & 0.0 & 0.0 & 0.0 & 0 \\
\hline Conventional & Tomato & 485.3 & 56.1 & 748.8 & 82 \\
\hline Organic & Sunn hemp and Japanese millet & 671.4 & 798.1 & 595.2 & 0 \\
\hline \multicolumn{6}{|l|}{ 2003-south half of plots } \\
\hline Disk fallow & Tomato & 485.3 & 56.1 & 748.8 & 82 \\
\hline Weed fallow & Tomato & 485.3 & 56.1 & 748.8 & 82 \\
\hline Bahiagrass & Tomato and bahiagrass & 485.3 & 56.1 & 748.8 & 82 \\
\hline Conventional & Tomato & 559.3 & 56.1 & 883.3 & 82 \\
\hline Organic & Tomato and Japanese millet & 671.4 & 798.1 & 595.2 & 0 \\
\hline \multicolumn{6}{|l|}{2004} \\
\hline Disk fallow & Tomato & 485.3 & 56.1 & 748.8 & 88 \\
\hline Weed fallow & Tomato & 485.3 & 56.1 & 748.8 & 88 \\
\hline Bahiagrass & Tomato and bahiagrass & 485.3 & 56.1 & 748.8 & 88 \\
\hline Conventional & Tomato & 559.3 & 56.1 & 883.3 & 88 \\
\hline Organic & Tomato and Japanese millet & 671.41 & 798.1 & 595.2 & 0 \\
\hline
\end{tabular}


Strip tillage into bahiagrass pasture. To establish bahiagrass ('Argentine') pasture, seed ( $\left.22.4 \mathrm{~kg} \mathrm{ha}^{-1}\right)$ was soil incorporated in August 2000 and fertilizer was applied using rates presented in Table 2. Additional fertilizer applications were made in April 2001 to 2002 and plots were overseeded with bahiagrass seed at a rate of $9 \mathrm{~kg} \mathrm{ha}^{-1}$ on 16 April 2001. The bahiagrass was mowed at 3 - to 4-week intervals during the growing season. In August 2003, strips were cultivated and the herbicide sethoxydim (Poast, BASF Corp., Research Triangle Park, NC) was applied at $0.4 \mathrm{~kg} \mathrm{ha}^{-1}$ in the south half of each replicate plot using procedures outlined by Chellemi et al. (13). In August 2004, the tilled strips were prepared in both the south and north half of each replicate plot. Fertilizer was applied in September using the rates described in Table 2 and tomato seedlings were transplanted into beds on 2 September 2003 and 6 October 2004. Tomato plants were pruned and cultivated on a trellis using commercial production methods. Plots were scouted weekly and treated when necessary for foliar pests. Grass in the row middles was managed using the herbicide sethoxydim applied at $0.4 \mathrm{~kg} \mathrm{ha}^{-1}$ at 4 weeks after transplanting and by mechanically mowing at 3 - to 4 -week intervals.

Disk fallow and weed fallow program. The disk fallow program consisted of periodic tillage conducted at intervals frequent enough to ensure plots were vegetation free. Soil was tilled to a $15 \mathrm{~cm}$ depth using $30 \mathrm{~cm}$ offset disks (leveling disk) followed by a pass with a cultivator containing swept back shanks attached to rolling baskets. In the weed fallow program, plots were maintained in an undisturbed state during the entire experiment. In August 2003, soil was prepared and tomato was cultivated in the south half of each replicate plot using the same procedures mentioned previously for conventionally managed plots except that soil fumigants were not applied. In August 2004, soil was prepared and tomatoes were cultivated in both the north and south halves of each replicate plot as described above.

Assessment of pest control and marketable yields. The incidence of Fusarium wilt of tomato was assessed by counting the number of plants with disease symptoms in each replicate plot and dividing by the total number of plants present in each replicate plot. Each season, Koch's postulates were performed to verify visual diagnosis by removing roots from four symptomatic tomato plants. Crown tissue with symptomatic necrosis of phloem tissue was washed in tap water, cut into $1-\mathrm{cm}$ sections, and surface sterilized with $\mathrm{NaOCl}\left(1,000 \mu \mathrm{g} \mathrm{liter}^{-1}\right)$ for $90 \mathrm{~s}$ followed by a 90-s rinse with sterile deionized water. Roots were blotted dry on sterile paper towels and plated onto an agar medium containing $39 \mathrm{~g} \mathrm{liter}^{-1}$ of Difco potato dextrose agar, ampicillin at $0.25 \mathrm{~g} \mathrm{liter}^{-1}$, rifampicin at $0.01 \mathrm{~g} \mathrm{liter}^{-1}$, and $0.1 \mathrm{ml}$ of tergitol. Plates were incubated in the dark at $27^{\circ} \mathrm{C}$ with $8 \mathrm{~h}$ per day of fluorescent light. Fungal colonies identified as $F$. oxysporum were tested for pathogenicity on tomato seedlings ('Bonny Best', Totally Tomatoes, Augusta, GA) using a root method described by Bao et al. (1). Root galling from Meloidogyne spp. was determined by removing the root systems from six plants in each replicate plot and rating for galling on a 0 to 10 scale based on the percentage of the root system with galls: $0=0 \%$ of the root system with galls, $1=10 \%$ of the root system with galls, $2=20 \%$ of the root system with galls, etc., up to $10=100 \%$ of the root system galled. Yield data were obtained by harvesting 12 contiguous plants from each replicate plot. Fruit was evaluated for marketability based upon USDA grading standards for size and appearance. Marketable fruit were weighed and yield was determined.

Molecular methods. Soil samples were collected at harvest in December 2003 and January 2005 by bulking soil obtained from the root zone of four tomato plants from each replicate plot. DNA was extracted from soil samples using a commercially available soil DNA extraction kit (UltraClean Soil DNA Isolation Kit, Mo Bio Laboratories, Solana Beach, CA) and preserved at $-20^{\circ} \mathrm{C}$ until use. Polymerase chain reaction (PCR) primers specific for the internal transcriber spacer 1 (ITS1) of fungal DNA and bac- terial 16S rDNA were used to examine microbial community composition following procedures previously described by $\mathrm{Wu}$ et al. (57,59). Amplicon length heterogeneity PCR (LH-PCR) was used to amplify the fungal and bacterial DNA and labeled amplicons were separated by laser-induced fluorescence (Applied Biosystems 3730xl DNA Analyzer, Foster City, CA).

Statistical analysis. Analysis of variance was performed to determine the effect of land management practices on the incidence of Fusarium wilt of tomato, the severity of root galling, and marketable yield of tomato. A general linear models procedure and Duncan's multiple range test and critical ranges were used to compare treatment means (Statistica, StatSoft, Inc., Tulsa, OK). Data were analyzed as a randomized block design with six replications in year 4 (2003) and as a randomized complete block with split plots in year 5 (2004). Main plots were land management practice and split plots in 2004 were the north half (maintained under land management practice in years 1 to 4 , planted to tomato in year 5) and the south half (land management practice in years 1 to 3 and tomato cultivation in years 4 and 5). Root-gall ratings were converted to percentage of roots with galls prior to analysis and along with disease incidence data were normalized using the arcsine transformation. Graphical description of the resemblance of soil bacterial and fungal communities in various plots and their association with Fusarium wilt and root galling was performed using nonparametric multivariate procedures outlined by Clarke (15) and Clarke and Warwick (16) and the PRIMER-E statistical software (PRIMER-E Ltd., Plymouth Marine Laboratory, UK). Pairwise Bray-Curtis similarity matrices for samples were constructed using the relative abundance values for each DNA amplicon length (4). A square root transformation was applied to the data before construction of the similarity matrices. Interrelationships between samples were mapped in ordination plots using nonmetric multidimensional scaling (MDS), where the position of each sample is determined by its distance from all other points in the analysis and the "stress" represents a measure of the goodness of fit of the plot (31). A stress value of $<0.20$ indicates a useful two-dimensional picture (15). The application of nonmetric MDS to the analysis of soil microbial community structure was previously described (9). The incidence of Fusarium wilt or the percentage of roots with galls were superimposed over each sample point in the ordination plot using circles scaled to reflect disease incidence or root gall severity, providing a visual guide to the association of soil fungal and bacterial community composition with damage from soilborne pests (16).

\section{RESULTS}

Incidence of Fusarium wilt. In year 4 (2003), land management practice significantly affected the incidence of Fusarium wilt (Table 3). Disease was higher in disk and weed fallow plots when compared with plots in a bahiagrass rotation or subjected to organic or conventional production practices (Fig. 1). In year 5 (2004), land management practice also significantly impacted Fusarium wilt (Table 3). In plots where different land management practices were previously employed for 4 years, Fusarium wilt was highest in the disk fallow plots when compared with disease in other plots (Fig. 1). Fusarium wilt was intermediate in plots previously maintained as weed fallow or subjected to conventional tomato production. Disease was lowest in plots subjected to organic production practices or a bahiagrass rotation. Cultivation of tomato over two consecutive years had a significant impact on the incidence of Fusarium wilt (Table 3), with an increase in disease observed in all land management programs except organic (Fig. 1).

Severity of root galling. In 2003, land management practice significantly affected the percentage of tomato roots with galls from Meloidogyne spp. (Table 3). Root galling was highest in the weed fallow plots, with over $80 \%$ of the root system covered with 
galls (Fig. 2). Damage was moderate in the plots subjected to the bahiagrass rotation $(15 \%)$ when compared with root galling in disk fallow, organic, or conventional tomato production plots $(<5 \%)$. In 2004, land management practice significantly affected the percentage of tomato roots with galls from Meloidogyne spp. (Table 3). Root galling was highest following 4 years of weed fallow (Fig. 2). A moderate level of root galling was observed in the bahiagrass plots despite a 4-year rotation. The percentage of roots with galls was minimal $(<1 \%)$ in plots subjected to repeated tillage, organic, or conventional production practices. While the impact of tomato cultivation for two consecutive years was not significant $(P=0.12)$, an increase in the severity of root galling was noted for all plots except those subjected to a bahiagrass rotation or an organic management regime.

TABLE 3. $F$ and probability values for the effect of land management strategies on the incidence of Fusarium wilt of tomato, damage to tomato roots from Meloidogyne spp. (\% of roots with galls), and marketable yield of tomato ${ }^{\mathrm{a}}$

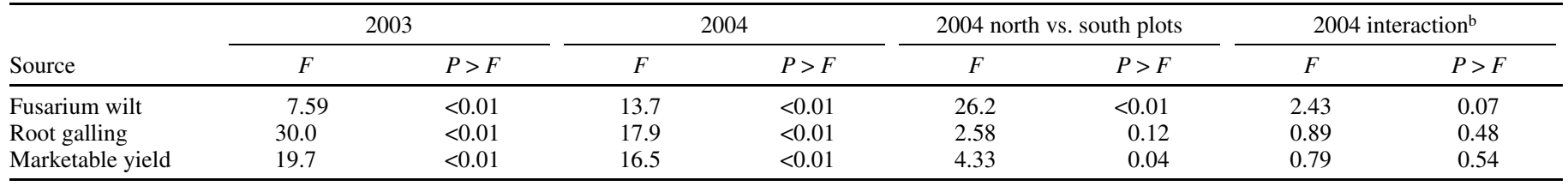

a Probabilities greater than $F$ from analysis of variance using the general linear models procedure.

${ }^{\mathrm{b}}$ Interaction between plot location (north, south) and land management treatment.
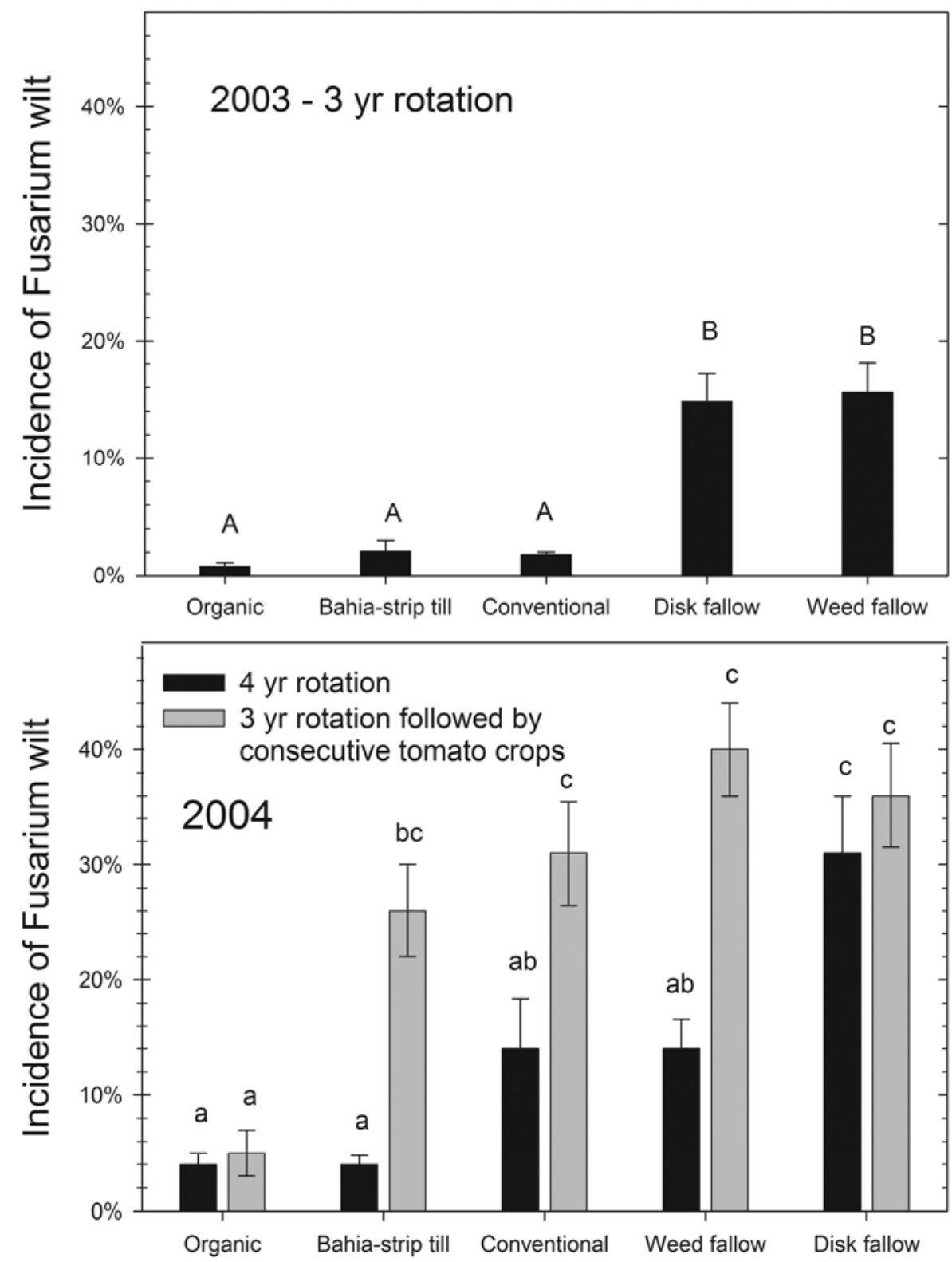

Fig. 1. Incidence of Fusarium wilt of tomato (Fusarium oxysporum f. sp. lycopersici) following a 3- or 4-year rotation under various land management regimes and after successive tomato crops. Error bars represent the standard error. Main effect means for land management strategy (A and B) followed by the same letter do not differ according to Duncans' multiple range test $(P \leq 0.05)$. Means for the interaction of land management strategy and years of consecutive tomato cultivation followed by the same letter (a to d) do not differ according to Duncans' multiple range test $(P \leq 0.07)$. 
Marketable yield. Land management practice significantly affected marketable yield of tomato in 2003 (Table 3). Yield was highest in plots managed conventionally or previously subjected to continuous tillage, moderate in plots managed organically or as a weed fallow, and lowest in the strip-till bahiagrass plots (Fig. 3). Land management practice significantly affected marketable yield of tomato in 2004. Marketable yields were highest in the conventional, weed fallow, and disk fallow plots, moderate in the organic plots, and lowest in the bahiagrass plots. Consecutive years of tomato production significantly $(P=0.04)$ affected marketable yield (Table 3 ). A noticeable decline occurred when tomato was grown in consecutive years in plots previously maintained as disk fallow, weed fallow or bahiagrass. No decline in marketable yield was observed in the organically or conventionally managed regimes when tomato was cultivated over consecutive years (Fig. 3).

Association between soil microbial community composition, Fusarium wilt, and damage from Meloidogyne spp. Stress values of $<0.20$ were obtained in all ordination plots, indicating a good fit of the MDS analysis to the fungal and bacterial rDNA amplicon data. Fungal ITS1 amplicons associated with organically managed plots shared $40 \%$ similarity with each other, based upon pairwise Bray-Curtis similarity matrices, when compared with fungal ITS1 amplicons identified from other land manage- ment plots (Fig. 4). In 2004, amplicons from plots subjected to 4 years of organic practices were split into two groups. Amplicons from the bahiagrass rotations shared $40 \%$ similarity with each other in 2003 and 2004. However, when the 3-year rotation was followed by consecutive years of tomato, communities of fungal amplicons from the bahiagrass plots were more similar in composition to communities from conventional, disk fallow and weed fallow plots. Overlays of the incidence of Fusarium wilt in individual plots (solid circles) indicated low disease incidence was associated with communities of fungal amplicons in organic and bahiagrass plots, which remained distinct in comparison to communities in the other plots. As communities of fungal ITS amplicons in the bahiagrass plots became more similar to communities in the conventional, disk fallow, and weed fallow plots, the incidence of Fusarium wilt also increased.

A similar trend was also observed for communities of bacterial 16S rDNA amplicons identified from organic plots but not for amplicons identified from bahiagrass rotations (Fig. 5). In 2003, bacterial amplicons from the bahiagrass plots shared at least $40 \%$ similarity to amplicons from three weed fallow plots associated with higher incidences of Fusarium wilt. When the 3-year rotation was followed by consecutive tomato crops, amplicons from five of the six bahiagrass plots shared a $40 \%$ similarity to amplicons from the weed fallow, disk fallow, and conventional plots. With
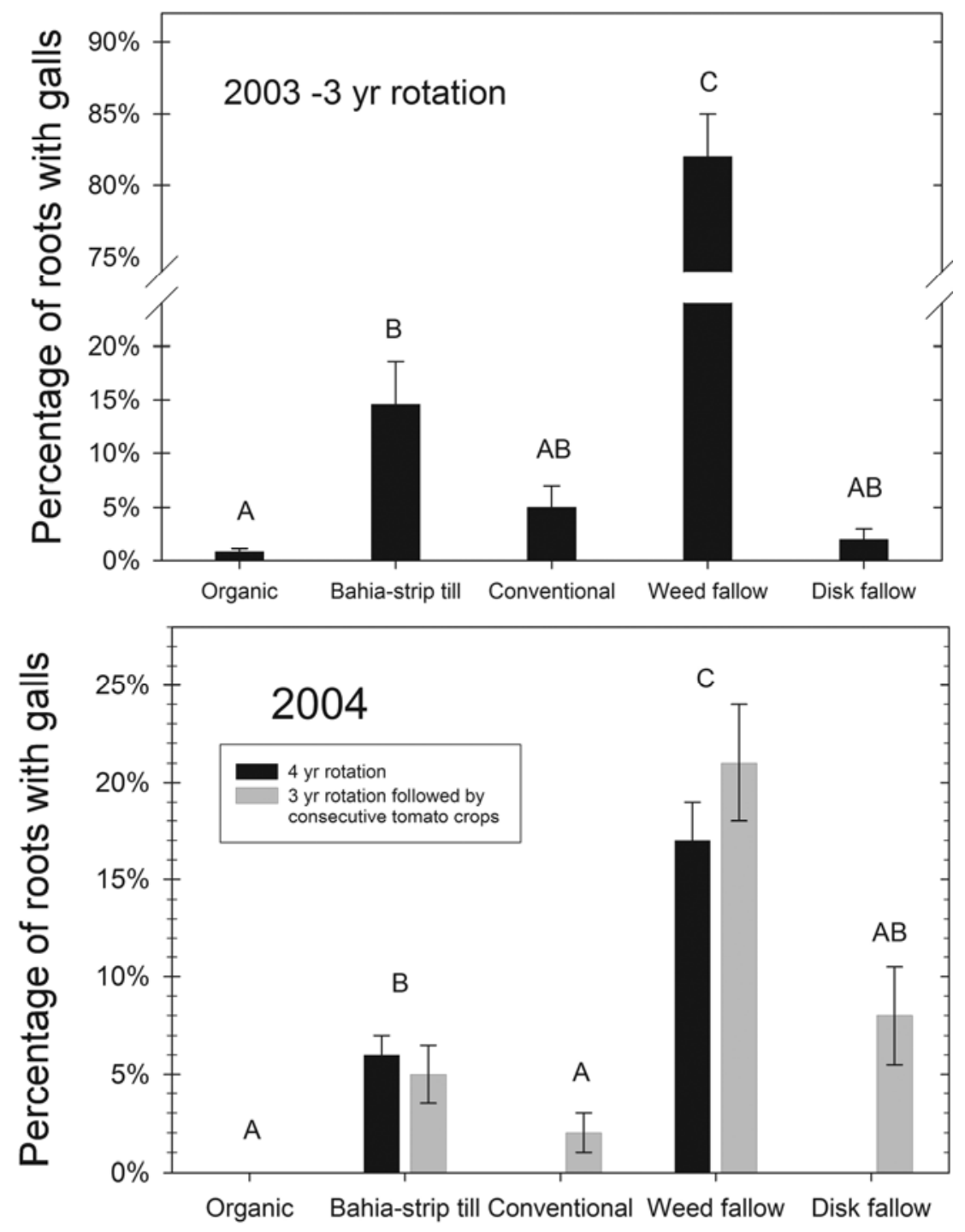

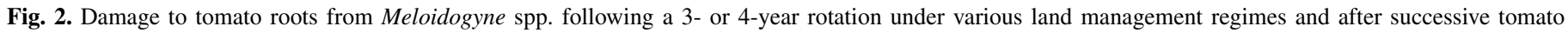

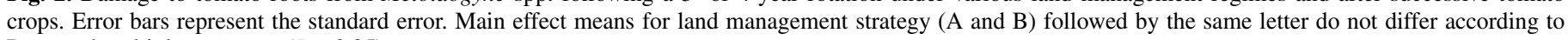
Duncans' multiple range test $(P \leq 0.05)$. 
the exception of one organic plot, higher incidences of Fusarium wilt were also associated with those plots sharing at least $40 \%$ similarity.

\section{DISCUSSION}

The field plot design used in this study addressed several factors affecting interpretation of results from long-term field experiments. Soil type is a primary determinant of microbial community structure in arable soils $(7,22,42)$. The impact of soil particle size on water and substrate availability, gas diffusion, and protection from predation $(39,46)$ can obscure the effects of agricultural land management practices on soil microbial community dynamics and attempts to measure their association with plant disease. On a macroscale, interplot interference from wind-driven rain, flooding, and movement of equipment or people can confound the interpretation of results. This study mitigated the effects of soil type and interplot interference by locating plots within a uniform soil type while ensuring they were large enough size
(0.16 ha) to permit physical separation. The incidence of Fusarium wilt of tomato and the percentage of tomato roots with galls were consistent in 2003 and 2004 within respective land management treatments despite direct strikes from two major hurricanes (Francis and Jean) in 2004. Analysis of soil fungal and bacterial communities and root colonizing fungi from individual plots revealed consistencies in the composition with respect to their land management practice despite the hurricanes of 2004 (41,57-59).

Plant species composition in weed fallow plots was not determined, but the vegetative growth was extensive enough to cover the soil surface, providing ample opportunities for $F$. oxysporum $\mathrm{f}$. sp. lycopersici to colonize plant roots and survive. Conversely, the disk fallow plots remained void of all plant material for 3 to 4 years. Despite a lack of plant hosts, the incidence of Fusarium wilt of tomato in disk fallow plots was similar (2003) or significantly higher (2004) than the incidence in weed fallow plots. Other plant-pathogenic Fusarium spp. including F. graminearum, $F$. culmorum, and $F$. avenaceum have been observed to
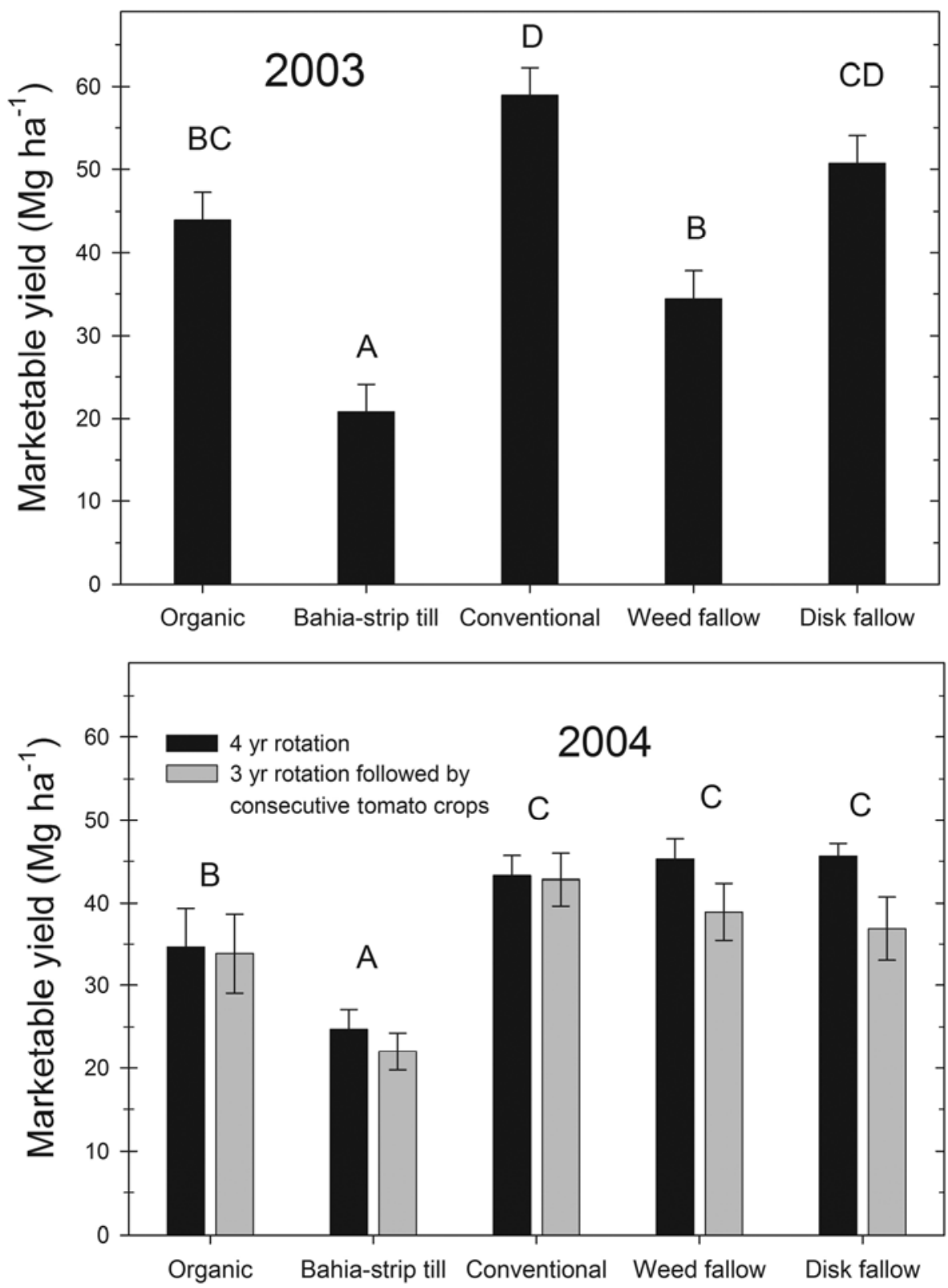

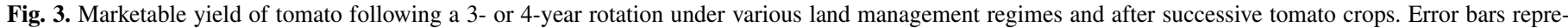

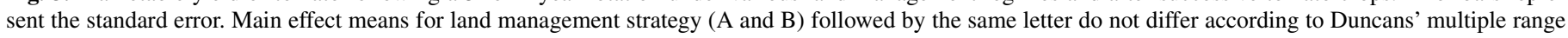
test $(P \leq 0.05)$. 
cause higher levels of disease following soil tillage when compared with disease in plots without tillage (6). However, differences in disease were attributed to soil environmental conditions including moisture and temperature (6), which would not apply to this study as the tomato crops were produced under identical irrigation regimes in soil covered by polyethylene mulch. In many soil ecosystems, the primary regulator for plant disease is a food source for the pathogen, usually provided by a susceptible plant hosts or undecomposed infected crop residue. The high incidence of disease in soil maintained free of vegetation up to 4 years suggests that $F$. oxysporum $\mathrm{f}$. sp. lycopersici can survive for long periods of time without a food source and that tillage may facili-

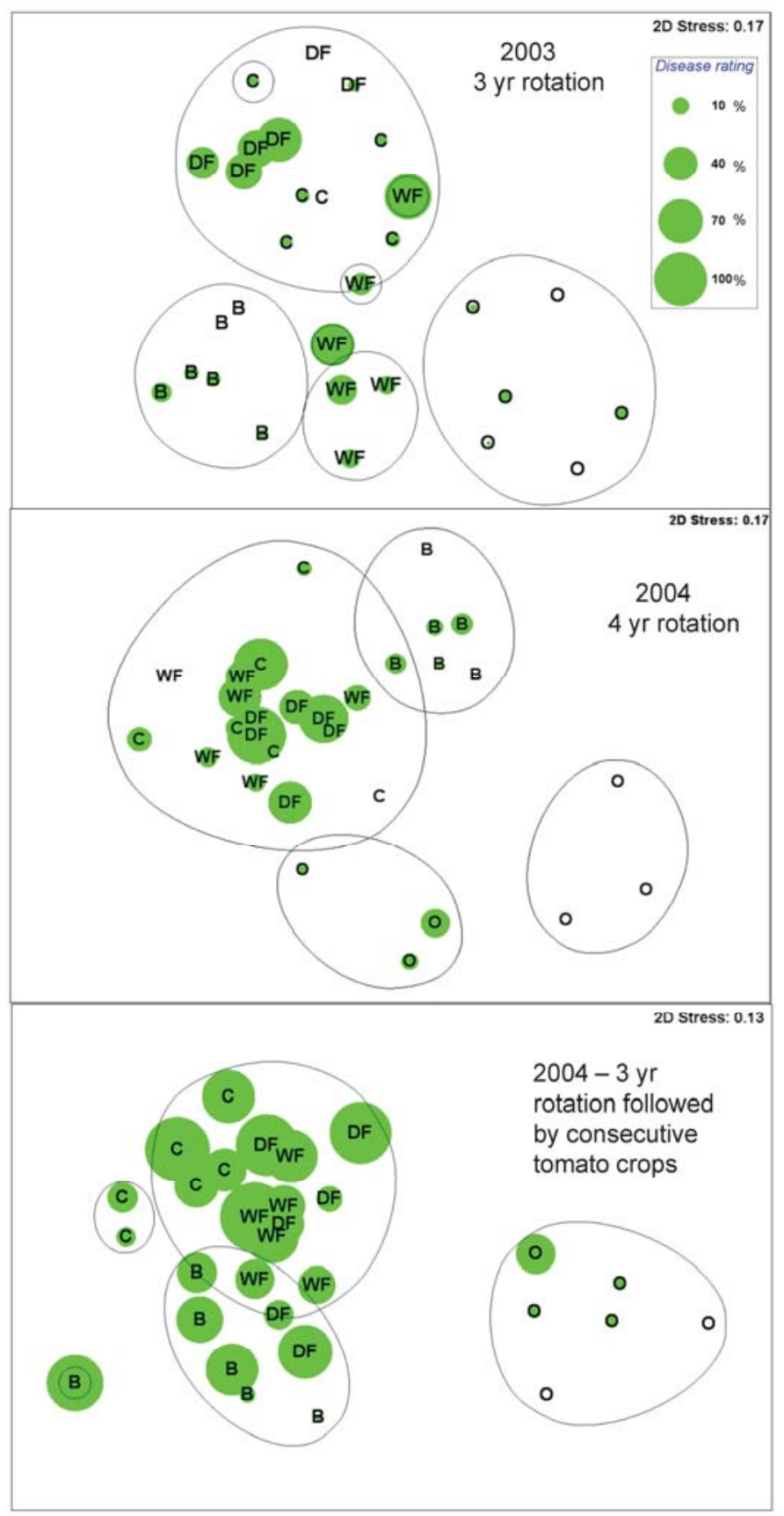

Fig. 4. Association of the effect of land management regimes on the community composition of fungal internal transcribed spacer 1 (ITS1) rDNA amplicons and the incidence of Fusarium wilt. $\mathrm{C}=$ conventional tomato production, $\mathrm{O}=$ organic tomato production, $\mathrm{B}=$ bahiagrass strip-tillage tomato production, $\mathrm{DF}=$ tomato production after a disk fallow regime, and $\mathrm{WF}=$ tomato production after a weed fallow regime. Solid circles reflect reflect the incidence of Fusarium wilt in plots. The black circular lines represent a shared similarity level of $40 \%$ for the composition of fungal ITS1 rDNA amplicons. tate wider distribution of infective propagules in soil. In companion studies examining soil fungal populations in greater detail, F. oxysporum comprised $19 \%$ of the fungal isolates identified from tomato roots using culture-based methods in the disk and weed fallow plots (58). Furthermore, a 341-bp ITS1 amplicon, identified as $F$. oxysporum, was the dominant amplicon in soil fungal communities from the disk and weed fallow plots (59). The ability to survive long periods of time without plant hosts may extend to other root colonizing fungi as well. Arbuscular mycorrhizal fungi and other fungal root endophytes also demonstrated a high degree of resiliency by rapidly rebounding on tomato roots after the extended disk fallow periods (40).

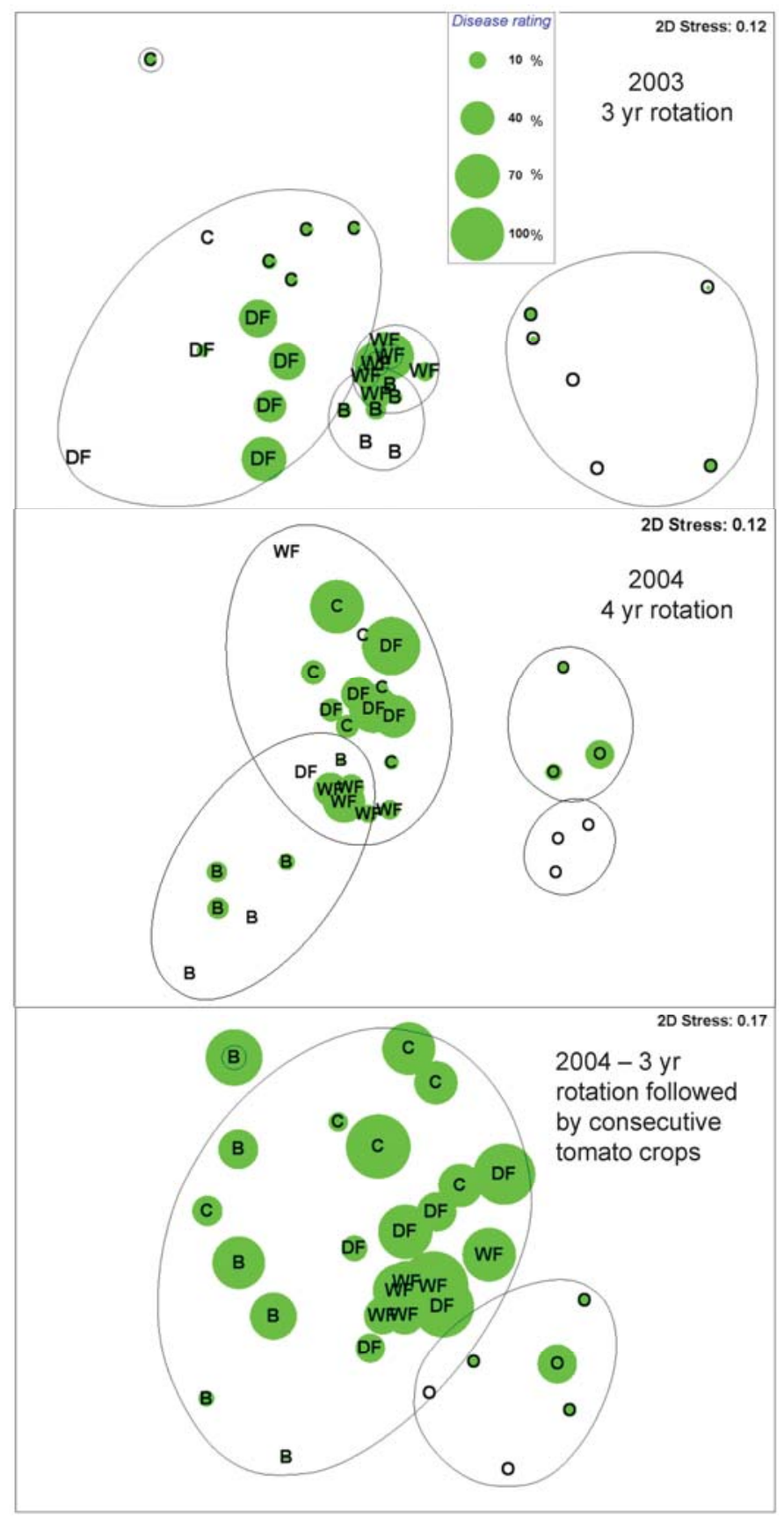

Fig. 5. Association of the effect of land management regimes on the community composition of bacterial $16 \mathrm{~S}$ rDNA amplicons and the incidence of Fusarium wilt. $\mathrm{C}=$ conventional tomato production, $\mathrm{O}=$ organic tomato production, $\mathrm{B}=$ bahiagrass strip-tillage tomato production, $\mathrm{DF}=$ tomato production after a disk fallow regime, and $\mathrm{WF}=$ tomato production after a weed fallow regime. Solid circles reflect the incidence of Fusarium wilt in plots. The black circular line represents a shared similarity of $40 \%$ for the composition of bacterial 16S rDNA amplicons. 
The extended absence of a food source significantly mitigated damage from Meloidogyne spp., as evidenced by reductions in root galling to levels below $2 \%$ in the disk fallow plots. In a Florida loamy sand, the density of Meloidogyne spp. was not affected by 25 years of tillage when compared with adjacent plots managed under no-tillage (52). However, those results were based upon a single soil sample collected after fields were left fallow with weeds for 1.5 years. Long-term (4 years) soil tillage has been shown to reduce the density of Meloidogyne spp. in other regions (37). Superimposing the percentage of roots with galls over MDS plots of the pairwise Bray-Curtis similarity coefficients for soil

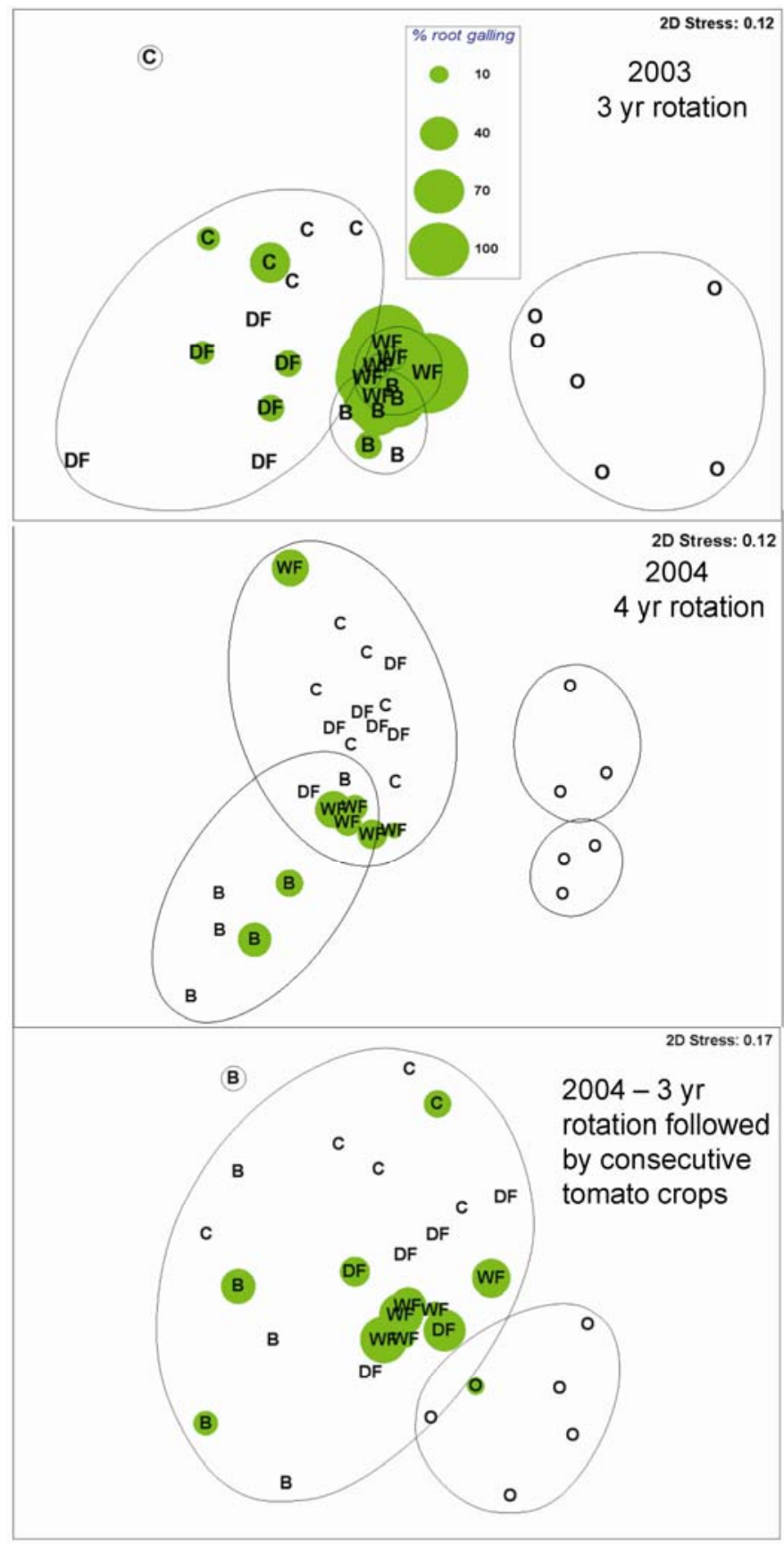

Fig. 6. Association of the effect of land management regimes on the community composition of bacterial $16 \mathrm{~S}$ rDNA amplicons and the severity of root galling by Meloidogyne spp. $\mathrm{C}=$ conventional tomato production, $\mathrm{O}=$ organic tomato production, $\mathrm{B}=$ bahiagrass strip-tillage tomato production, $\mathrm{DF}=$ tomato production after a disk fallow regime, and $\mathrm{WF}=$ tomato production after a weed fallow regime. Solid circles reflect the severity of root galling $(\%$ galls) in plots. The black circular line represents a shared similarity of $40 \%$ for the composition of bacterial $16 \mathrm{~S}$ rDNA amplicons. bacterial 16S rDNA amplicons revealed a high degree of association between soil bacterial communities in disk fallow plots and damage from Meloidogyne spp. (Fig. 6). A similar association was not observed when the percentage of roots with galls was superimposed over the composition of soil fungal ITS1 amplicons (Fig. 7).

The sod-based bahiagrass rotation provided a single season of control of Fusarium wilt of tomato. Disease incidence increased from 4 to $26 \%$ when a 3 -year rotation was followed by consecutive tomato crops in 2003 and 2004. The benefits from a single season of disease control do not outweigh the cost and time

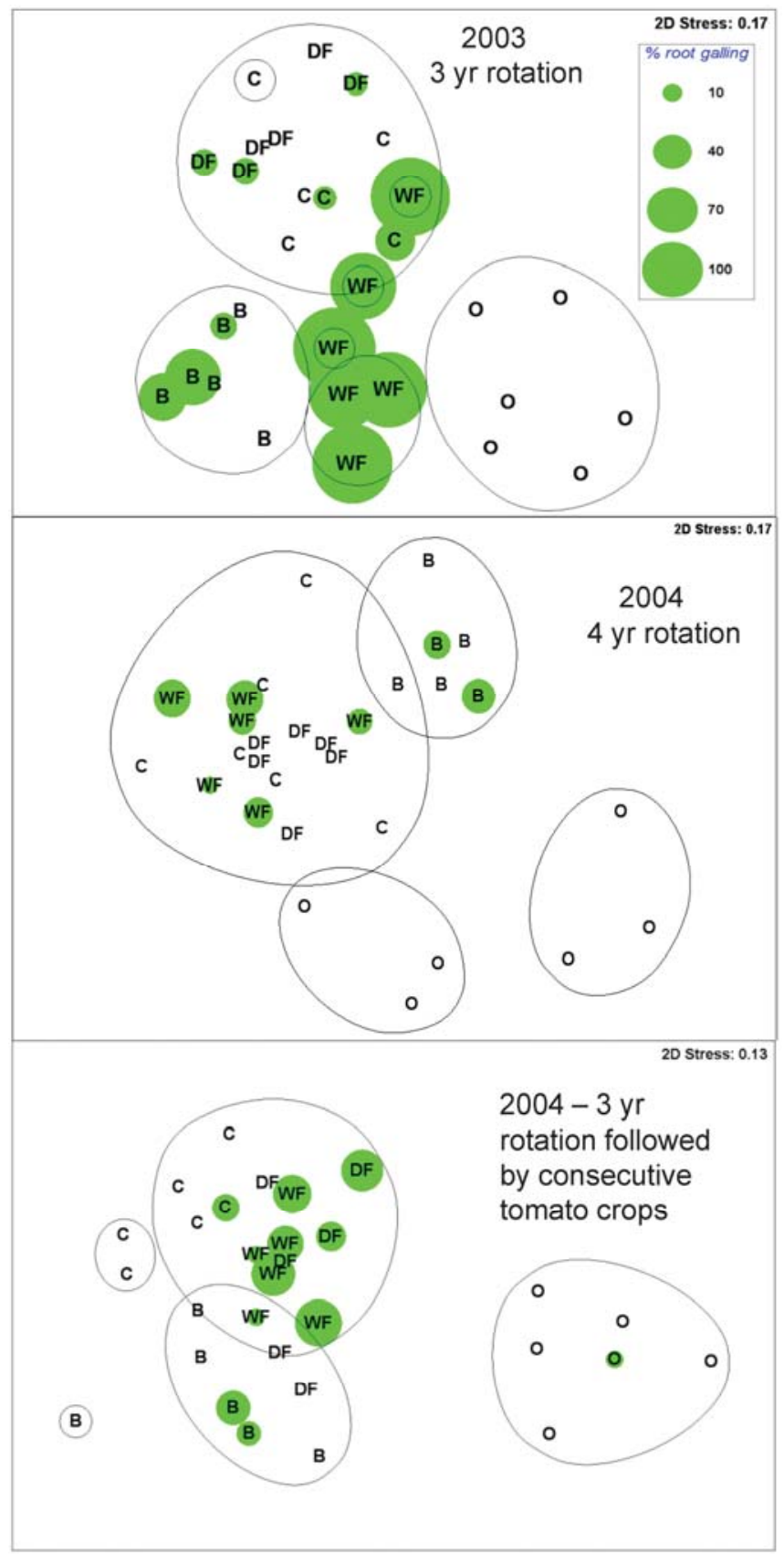

Fig. 7. Association of the effect of land management regimes on the community composition of fungal internal transcribed spacer 1 (ITS1) rDNA amplicons and the severity of root galling by Meloidogyne spp. $\mathrm{C}=$ conventional tomato production, $\mathrm{O}=$ organic tomato production, $\mathrm{B}=$ bahiagrass strip-tillage tomato production, $\mathrm{DF}=$ tomato production after a disk fallow regime, and $\mathrm{WF}=$ tomato production after a weed fallow regime. Solid circles reflect the severity of root galling (\% galls) in plots. The black circular lines represent a shared similarity level of $40 \%$ for the composition of fungal ITS1 rDNA amplicons. 
(3 years) required to plant and manage an improved stand of bahiagrass and the revenue lost by eliminating tomato production for several years. Tomato monoculture following the bahiagrass rotation was associated with a shift in the composition of soil fungal communities. When a single crop of tomato was cultivated after a 3- or 4-year bahiagrass rotation, nonmetric MDS ordination plots revealed a closer association among fungal ITS1 amplicons obtained from bahiagrass plots (40\% similarity) than amplicons obtained from other land management treatments (Fig. 5). Following a second consecutive tomato crop, the composition of soil fungal ITS1 amplicons in bahiagrass plots became more like the composition in disk fallow and weed fallow plots, providing additional biological evidence that the disease suppressive benefits from the bahiagrass rotation were not sustainable over multiple crops. Tomato was grown in the bahiagrass plots using strip-tillage techniques in which $2 / 3$ of the sod remained intact and growing. It is postulated that additional tillage to remove all bahiagrass roots would accelerate changes to soil fungal communities and result in further increases of Fusarium wilt of tomato. Similar biological impacts of a bahiagrass rotation on soil bacterial communities were not observed (Fig. 4). Following bahiagrass rotations of 3 or 4 years, the percentage of tomato roots with galls was 14 and $7 \%$, respectively. This was unexpected as there are numerous reports on the benefits in control of Meloidogyne spp. from bahiagrass rotations $(5,17,25,26,43)$. Although low levels of root galling were observed, damage from Meloidogyne spp. did not increase from repeated tomato cultivation indicating that benefits in nematode control were sustainable over several seasons.

In 2003, soil fumigation with 1,3-dichloropropene:chloropicrin provided significant control of Fusarium wilt of tomato and root galling from Meloidogyne spp. This was expected as this chemical approach to soilborne pest management was demonstrated to an effective alternative to soil fumigation with methyl bromide (44). In 2004, effective control of root galling by Meloidogyne spp. was achieved but the incidence of Fusarium wilt ranged from 15 to $31 \%$ in plots. One possible explanation for the higher incidence of disease in 2004 is that season long reductions in $F$. oxysporum f. sp. lycopersici by soil fumigation were compromised by the flooding and wind damage sustained from two hurricanes (Francis and Jean) directly impacting the sites on 4 and 25 September. Although soil fumigation can reduce the inoculum density of $F$. oxysporum, the fungus remained a dominant species in the conventional plots despite repeated applications of soil fumigants (59). Additionally, the soil fungal communities in conventional plots shared a $40 \%$ similarity to fungal communities subjected to disk and weed fallow management practices, which were associated with significantly higher incidences of Fusarium wilt.

The biological impacts organic production practices were consistent between years and sustainable over a repeated tomato monoculture. The incidence of Fusarium wilt and levels of root galling remained $<5 \%$ even when consecutive tomato were planted. Cultivation of sun hemp and Japanese millet cover crops as a nonhost for Meloidogyne spp. would contribute to the reductions in root galling. The reductions in Fusarium wilt appeared to be associated with changes in the composition of soil bacterial and fungal communities. Nonmetric MDS ordination plots revealed a separate cluster sharing $40 \%$ similarity that was comprised of sample points from organic plots. Samples from organic plots continued to share a higher similarity to each other when compared with samples from plots in other land management practices despite consecutive tomato crops. In the study by Wu et al. (58), less than $5 \%$ of fungal communities identified in soil or tomato roots obtained from the organic plots were comprised of F. oxysporum.

It is noteworthy that land management strategies associated with both the highest and lowest level of perturbation were the most conducive for Fusarium wilt of tomato. F. oxysporum demonstrated a capacity to thrive and cause significant levels of plant disease in both highly and minimally disturbed soil ecosystems but was compromised in a soil ecosystem characterized by moderate levels of disturbance (organic program). Rather than the sheer number of perturbations to a soil ecosystem, considering the form of perturbation may provide more insight into their effects on Fusarium wilt. For example, soil disturbance events can be differentiated into biological and physical components (48). In this study, addition of organic amendments and soil fumigation can be considered biological disturbance events, although their effects on soil microbial communities can differ immensely. Concomitantly, organic amendments alter the soil physical environment through increased organic matter content, soil aeration, and moisture holding capacity and thus may also be viewed as a physical disturbance. Another approach to differentiate the types of perturbation events and their possible outcomes on plant pathogens and plant disease is to identify whether the perturbation stresses or subsidizes the performance of the ecosystem (36). Within the context of soil microbial communities, biological control is considered a substrate-dependent phenomenon (24). In this study, the beneficial attributes of organic-based perturbations clearly subsidized performance of the agroecosystem in regards to plant disease suppression while the perturbations associated with the disk fallow strategy stressed the system through associated increases in root disease. The broiler litter used in this study was collected in pine bark shavings that lined the broiler production house floors. Amending soil with pine bark has been shown to affect the population density of soil microorganisms and plant parasitic nematodes (29). Moreover, amending soil with broiler litter was shown to alter the composition of fungal and bacterial communities in favor of beneficial microorganisms (45). Rotation crops and broiler litter were demonstrated to reduce soil densities of plant-parasitic nematodes in other regions $(28,34)$.

The application rate of broiler litter used for the organic regime in this study was significantly greater than the $4.5 \mathrm{Mg} \mathrm{ha}^{-1}$ recommended for agronomic crops on the southern coastal plain of Georgia (18) but was comparable to the $31.4 \mathrm{Mg} \mathrm{ha}^{-1}$ recommended for cotton lint yield and suppression of Columbia lance nematode in North Carolina (28). Application rates of broiler litter in excess of $20 \mathrm{Mg} \mathrm{ha}^{-1}$ are used by growers in the FEW undergoing transition from conventional to organic production (14) and there is evidence it contributes to reductions in soilborne disease (10). In regards to the sustainability of this pest management approach, the benefits of pest control from soil incorporation of organic amendments must be balanced against their detrimental environmental and health impacts. For example, soil incorporation of poultry litter effectively suppresses root-lesion nematodes (Pratylenchus penetrans) on susceptible crops in the Eastern Shore of Maryland (30) but accumulation of P in surface soils and potential runoff and eutrophication of adjacent bodies of water (38) has created concerns over its use.

Soil microbial communities are largely responsible for regulating ecosystem function in terrestrial systems through their effects on carbon flow, plant population dynamics, and soil physical environments $(3,27,55)$. Of particular interest is the natural ability of soils to regulate damaging outbreaks of plant disease and plantparasitic nematodes. Numerous studies have examined the impacts of farm and crop management practices on soilborne disease, plant-parasitic nematodes, or soil microbial diversity $(2,6,7,10$, $17-19,21,25,28-30,32-34,37,41,43,47,52,53)$ but few have examined their associations in depth $(29,41)$. Of the five agricultural land management practices examined in this study, soil fungal and bacterial community composition were most strongly influenced by the organic land management system $(57,59)$. This study identified an association between the composition of microbial communities identified in organically managed plots and the suppression of plant disease and damage to roots by Meloidogyne 
spp. and demonstrated the association was stable despite natural and anthropogenic disturbance events.

Under commercial production conditions, fruit harvested from plants with Fusarium wilt is unmarketable. Thus, yield data were obtained from tomato plants without symptoms of Fusarium wilt. In general, yields were lowest in the strip tillage-bahiagrass plots, intermediate in plots managed organically, and highest in the conventional, weed fallow and disk fallow plots. The lone exception was in 2003 , where severe galling ( $85 \%$ of root systems) impacted yield in the weed fallow plots. Other than soil fumigation in the conventional plots, identical production methods where used in the disk fallow and weed fallow plots. Moderate yields in the organic plots were attributed to the slower and more erratic release of nutrients from the broiler litter and urban plant debris when compared with the daily application of liquid fertilizer through the drip irrigation system in conventional, weed fallow and disk fallow plots. Higher returns for organically produced fruit and reduced loss from Fusarium wilt may offset some losses in revenue from lower yields. The significant yield reductions in the strip tillage-bahiagrass plots were attributed to competition for water and nutrients by the bahiagrass sod that remained in the row middles and was expected (13). However, in a commercial application of the strip tillage-bahiagrass system, the net return per acre was higher than neighboring conventionally produced tomatoes despite lower yields due to the reduction in input costs. In regards to the sustainability of the various land management approaches for tomato production in the FEW, marketable yield and changes in pest pressure due to continued monoculture must be factored together.

\section{ACKNOWLEDGMENTS}

We thank E. Killer, L. Markle, L. Therrien, J. Garces, K. Dover, and G. Ingram for technical support and Triangle Farms and Diamond Tomato for logistical support. Mention of a trademark, warranty, proprietary product, or vendor does not constitute a guarantee by the U.S. Department of Agriculture and does not imply its approval to the exclusion of other products or vendors that also may be suitable.

\section{LITERATURE CITED}

1. Bao, J. R., Fravel, D. R., O’Neill, N. R., Lazarovits, G., and van Berkum, P. 2002. Genetic analysis of pathogenic and nonpathogenic Fusarium oxysporum from tomato plants. Can. J. Bot. 80:271-279.

2. Baysal, F., Benitez, M. S., Kleinhenz, M. D., Miller, S. A., and McSpadden Gardener, B. B. 2008. Field management effects on dampingoff and early season vigor of crops in a transitional organic cropping system. Phytopathology 98:562-570.

3. Bever, J. D. 2003. Soil community feedback and the coexistence of competitors: Conceptual framework and empirical tests. New Phytol. 157:465-473.

4. Bray, J. R., and Curtis, J. T. 1957. An ordination of the upland forest communities of Southern Wisconsin. Ecol. Monogr. 27:325-349.

5. Brennehaman, T. B., Sumner, D. R., Baird, R. E., and Burton, G. W. 1995. Suppression of foliar and soilborne peanut diseases in bahiagrass rotations. Phytopathology 85:948:952.

6. Bockus, W. W., and Shroyer, J. P. 1998. The impact of reduced tillage on soilborne plant pathogens. Annu. Rev. Phytopathol. 36:485-500.

7. Bossio, D. A., Scow, K. M., Gunapala, N., and Graham, K. J. 1998. Determination of soil microbial communities: Effects of agricultural management, season, and soil type on phospholipid fatty acid profiles. Microbiol. Ecol. 36:1-12.

8. Chellemi, D. O. 2000. Adaptation of approaches to pest control in lowinput agriculture. Crop Prot. 19:855-858.

9. Chellemi, D. O. 2005. Multivariate statistical analysis of microbial community data. Published online by American Phytopathological Society, St. Paul, MN. http://www.scientificsocieties.org/aps/proceedings/ soilmicrobes/pdf/Chellemi.pdf.

10. Chellemi, D. O. 2006. Effect of urban plant debris and soil management practices on plant parasitic nematodes, Phytophthora blight and Pythium root rot of bell pepper. Crop Prot. 25:1109-1116.

11. Chellemi, D. O., Mirusso, J., Nance, J., and Shuler, K. 2001. Results from field scale demonstrations/validation studies of Telone products on the Florida east coast. Florida Tomato Institute Proc. Sept. 5, 2001. Citrus
Veg. Mag. 51-58.

12. Chellemi, D. O., Olson, S. M., Mitchell, D. J., Secker, I., and McSorley, R. 1997. Adaptation of soil solarization to the integrated management of soilborne pests of tomato under humid conditions. Phytopathology $87: 250-258$.

13. Chellemi, D. O., Rhoads, F. M., Olson, S. M., Rich, J. R., Murray, D., Murray, G., and Sylvia, D. M. 1999. An alternative low-input production system for fresh market tomatoes. Am. J. Alternative Agric. 14:59-68.

14. Chellemi, D. O., and Rosskopf, E. N. 2004. Yield potential and soil quality under alternative crops production practices for fresh market pepper. Renewable Agric. Food Sys. 19:168-175.

15. Clarke, K. R. 1993. Non-parametric multivariate analyses of changes in community structure. Aust. J. Ecol. 18:117-143.

16. Clarke, K. R., and Warwick, R. M. 2001. Change in Marine Communities: An Approach to Statistical Analysis and Interpretation, 2nd ed. Primer-E, Plymouth, UK.

17. Dickson, D. W., and Hewlett, T. E. 1989. Effects of bahiagrass and nematicides on Meloidogyne arenaria on peanut. J. Nematol. (Supp.) 21:671-676.

18. Gascho, G. J., Hubbard, R. K., Brenneman, T. B., Johnson, A. W., Sumner, D. R., and Harris, G. H. 2001. Effects of broiler litter in an irrigated, double-cropped, conservation-tilled rotation. Agron. J. 93:13151320.

19. Geraldson, C. M., Overman, A. J., and Jones, J. P. 1965. Combination of high analysis fertilizers, plastic mulch and fumigation for tomato production on old agricultural land. Soil Crop Soc. Fla. Proc. 25:18-24.

20. Gilbert, R. A., Rice, R. W., and Lentini, R. S. 2008. Characterization of selected mineral soils used for sugarcane production. University of Florida/IFAS Extension publication SS-AGR-227.

21. Gilreath, J. P., Noling, J. W., Gilreath, P. R., and Jones, J. P. 1997. Field validation of 1,3-dichloropropene + chloropicrin and pebulate as an alternative to methyl bromide in tomato. Proc. Fla. State Hort. Soc. 110:273-276.

22. Girvan, M. S., Bullimore, J., Pretty, J. N., Osborn, M. A., and Ball, A. S 2003. Soil type is the primary determinant of the composition of the total and active bacterial communities in arable soils. Appl. Environ. Microbiol. 69:1800-1809.

23. Hayslip, N. C., Allen, R. J., and Darby, J. F. 1952. A vegetable-pasture rotation study at the Indian River Field Laboratory. Proc. Fla. State Hort. Soc. $65: 148-153$.

24. Hoitink, H., and Boehm, M. 1999. Biocontrol within the context of soil microbial communities: A substrate-dependent phenomenon. Annu. Rev. Phytopathol. 37:427-446.

25. Johnson, A. W., Minto, N. A, Brenneman, T. B., Burton, G. W., Culbreath, A. K., and Gascho, G. J. 1999. Bahiagrass, corn, cotton rotations, and pesticides from managing nematodes, diseases, and insects on peanut. J. Nematol. 31:191-200.

26. Katsvairo, T. W., Rich, J. R., and Dunn, R. A. 2006. Perennial grass rotation: An effective and challenging tactic for nematode management with many other positive effects. Pest Manage. Sci. 62:793-796.

27. Kennedy, A. C., and Smith, K. L. 1995. Soil microbial diversity and the sustainability of agricultural soils. Plant Soil 170:75-86.

28. Koenning, S. R., and Barker, K. R. 2004. Influence of poultry litter applications on nematode communities in cotton agroecosystems. J. Nematol. 36:524-533.

29. Kokalis-Burelle, N., and Rodiguez-Kabana, R. 1994. Changes in populations of soil microorganisms, nematodes, and enzyme activity associated with application of powdered pine bark. Plant Soil 162:169-175.

30. Kratochvil, R. J., Sardanelli, S., Everts, K., and Gallagher, E. 2004. Evaluation of crop rotation and other cultural practices for management of root-knot and lesion nematodes. Agron. J. 96:1419-1428.

31. Kuskal, J. B., and Wish, M. 1978. Multidimensional Scaling. Sage, Beverly Hills, CA.

32. Lewis, J. A., Lumsden, R. D., Milner, P. D., and Keinath, A. P. 1992. Suppression of damping-off of peas and cotton in the field with composted sewage sludge. Crop Prot. 11:260-266

33. Locascio, S. J., Gilreath, J. P., Dickson, D. W., Kucharek, T. A., Jones, J. P., and Noling, J. W. 1997. Fumigant alternatives to methyl bromide for polyethylene mulched tomato. HortScience 32:1208-1211.

34. McSorley, R., Dickson, D. E., de Brito, J. A., and Hochmuth, R. C. 1994. Tropical rotation crops influence nematode densities and vegetable yields. J. Nematol. 26:308-314.

35. Obreza, T. A., and Collins, M. E. 2002. Commons soils used for citrus production in Florida. University of Florida/IFAS Extension Publication SL 193.

36. Odum, E. P., Finn, J. T., and Franz, E. H. 1979. Perturbation theory and the subsidy-stress gradient. BioScience 29:349-352.

37. Okada, H., and Harada, H. 2007. Effects of tillage and fertilizer on nematode communities in a Japanese soybean field. Appl. Soil Ecol. 35:582-598. 
38. Pote, D. H., Daniel, T. C., Sharpley, A. N., Moore, P. A., Jr., Edward, D. R., and Nichols, D. J. 1996. Relating extractable soil phosphorus to phosphorus losses in runoff. Soil Sci. Soc. Am. J. 60:855-859.

39. Ranjard, L., and Richaume, A. 2001. Quantitative and qualitative microscale distribution of bacteria in soil. Res. Microbiol. 152:707-716.

40. Rasmann, C., Graham, J. H., Chellemi, D. O., Datnoff, L. E., and Larsen, J. 2009. Resilient populations of root fungi occur within five tomato production systems in southeast Florida. Appl. Soil Ecol. 43:22-31.

41. Riegel, C., and Noe, J. P. 2000. Chicken litter soil amendment effects on soilborne microbes and Meloidogyne incognita on cotton. Plant Dis. 84:1275-1281.

42. Rime, D., Nazaret, S., Gourbiere, F., Cadet, P., and Moenne-Loccoz, Y. 2003. Comparison of sandy soils suppressive or conducive to ectoparasitic nematode damage on sugarcane. Phytopathology 93:1437-1444.

43. Rodriguez-Kabana, R., Robertson, D. G., Weaver C. F., and Wells, L. 1991. Rotations of bahiagrass and castor bean with peanut for the management of Meloidogyne arenaria. J. Nematol. (Supp.) 23:658-661.

44. Rosskopf, E. N., Chellemi, D. O., Kokalis-Burelle, N. K., and Church, G. T. 2005. Alternatives to methyl bromide: A Florida perspective. Plant Health Progress. doi:10-1094/PHP-2005-1027-01-RV.

45. Saison, C., Degrange, V., Oliver, R., Millard, P., Commeaus, C., Montange, D., and Le Roux, X. 2006. Alteration and resilience of the soil microbial community following compost amendment: Effects of compost level and compost-borne microbial community. Environ. Microbiol. 8:247-257.

46. Sessitisch, A., Weilharter, A., Gerzabek, M. H., Kirchmann, H., and Kandeler, E. 2001. Microbial population structures in soil particle size fractions of a long-term fertilizer field experiment. Appl. Environ. Microbiol. 67:4215-4224.

47. Stone, A. G., Vallad, G. E., Cooperband, L. R., Rotenberg, D., Darby, H. R., James, R. V., Stevenson, W. R., and Goodman, R. M. 2003. Effect of organic amendments on soilborne and foliar diseases in field-grown snap bean and cucumber. Plant Dis. 87:1037-1042.

48. Svensson, J. R., Lindegarth, M., and Pavia, H. 2010. Physical and biological disturbances interact differently with productivity: Effects on floral and faunal richness. Ecology 91:3069-3080.
49. USEPA. 2000. Protection of stratospheric ozone: Incorporation of clean air act amendments for reductions in class I, group VI controlled substances. Fed. Regist. 65:70795-70804.

50. USEPA. 2008. Chloropicrin, dazoment, metam sodium/potassium, and methyl bromide reregistration eligibility decisions; notice of availability. Fed. Regist. 73:40871-40873.

51. van Bruggen, H. C. 1995. Plant disease severity in high-input compared to reduced-input and organic farming systems. Plant Dis. 79:976-984

52. Wang, K. H., McSorley, R., and Gallaher, R. N. 2004. Relationship of soil management history and nutrient status to nematode community structure. Nematropica 34:83-95.

53. Wang, K. H., McSorley, R., and Kokalis-Burelle, N. 2006. Effects of cover cropping, solarization, and soil fumigation on nematode communities. Plant Soil 286:229-243.

54. Watts, F. C., and Stankey, D. L. 1980. Soil survey of St. Lucie County area, Florida. USDA, Soil Conservation Service; University of Florida, Institute of Food and Agricultural Sciences; and Florida Department of Agriculture and Consumer Services.

55. Went, F., and Stark, N. 1968. The biological and mechanical role of soil fungi. Proc. Natl. Acad. Sci. 60:497-504.

56. Winsberg, T., Chellemi, D. O., Mellinger, M., and Shuler, K. D. 1998. Transition to a biorational farm management system using soil solarization in a commercial pepper operation. Proc. Fla. State Hort. Soc. 111:78-79.

57. Wu, T., Chellemi, D. O., Graham, J. H., Martin, K. J., and Rosskopf, E. N. 2008. Comparison of soil bacterial communities under diverse agricultural land management and crop production practices. Microbiol. Ecol. 55:293-310.

58. Wu, T., Chellemi, D. O., Graham, J. H., and Rosskopf, E. N. 2008 Assessment of fungal communities in soil and tomato roots subjected to diverse agricultural land and crop management systems. Soil Biol. Biochem. 40:1967-1970.

59. Wu, T., Chellemi, D. O., Martin, K. J., Graham, J. H., and Rosskopf, E. N. 2007. Discriminating the effects of agricultural land management practices on soil fungal communities. Soil Biol. Biochem. 39: 1139-1155. 